\title{
Molecular alterations and clinical prognostic factors for cholangiocarcinoma in Thai population
}

\author{
N Trachu' ${ }^{1,2}$ \\ E Sirachainan ${ }^{3}$ \\ N Larbcharoensub ${ }^{4}$ \\ W Rattanadech ${ }^{3}$ \\ S Detarkom ${ }^{3}$ \\ N Monnamo' \\ K Kamprerasart ${ }^{4}$ \\ D MunTham ${ }^{5}$ \\ C Sukasem ${ }^{6,7}$ \\ T Reungwetwattana ${ }^{3}$
}

'Research Center, Faculty of Medicine Ramathibodi Hospital, ${ }^{2}$ Molecular Medicine Program, Multidisciplinary Unit, Faculty of Science, ${ }^{3}$ Division of Medical Oncology, Department of Medicine, ${ }^{4}$ Division of Anatomical Pathology, Department of Pathology, Faculty of Medicine Ramathibodi Hospital, Mahidol University, ${ }^{5}$ Section for Mathematic, Faculty of Science and Technology, Rajamangala University of Technology Suvarnabhumi, ${ }^{6}$ Division of Pharmacogenomics and Personalized Medicine, Department of Pathology, ${ }^{7}$ Laboratory for Pharmacogenomics, Somdech Phra Debaratana Medical Center (SDMC), Faculty of Medicine Ramathibodi Hospital, Mahidol University, Bangkok, Thailand
Correspondence: T Reungwetwattana Division of Medical Oncology, Department of Medicine, Faculty of Medicine Ramathibodi Hospital, Mahidol University, Bangkok, 10400, Thailand Tel +66220 l 167|

Fax +6626435648

Email thanyanan.reu@mahidol.ac.th
This article was published in the following Dove Press journal:

OncoTargets and Therapy

II October 2017

Number of times this article has been viewed

Abstract: This study explores genomic alterations in cholangiocarcinoma (CCC) tissues in Thai patients. We identified and reviewed the records of patients who had been diagnosed with CCC and for whom sufficient tumor samples for DNA and RNA extraction were available in our database. The specimens were explored for EGFR, KRAS, BRAF, and PIK3CA mutations and ROS1 translocation in 81 samples. Immunohistochemistry staining for HER2, ALK, and Ki-67 expression was tested in 74 samples. Prevalence of EGFR, KRAS, and PIK3CA mutations in this study was $21 \%, 12 \%$, and $16 \%$, respectively. No BRAF V600 mutation or ROS1 translocation was found. Patients with $T 790 M$ mutation had a significantly longer overall survival (18.84 months) than those with the other types of EGFR mutations (4.08 months; hazard ratio [HR]: $0.26, P=0.038)$ and also had a significantly lower median Ki-67 $(22.5 \%$ vs $80 \%$, $P=0.025)$. Furthermore, patients with $P I K 3 C A$ mutations had a significantly longer median progression-free survival (15.87 vs 7.01 months; HR: 0.46, $P=0.043$ ). Strongly positive HER2 expression was found in only 1 patient, whereas ALK expression was not found. The presence of EGFR and/or PIK3CA mutations implies that targeted drugs may provide a feasible CCC treatment in the future.

Keywords: cholangiocarcinoma, targeted therapy, gene alterations

\section{Introduction}

Biliary tract cancer (BTC) consists of both cholangiocarcinoma (CCC) and gallbladder cancer. Approximately $90 \%$ of BTCs are adenocarcinoma arising from the epithelial lining of the gallbladder and intrahepatic and extrahepatic bile duct. CCC is classified, according to its anatomical location in biliary tract, into 3 subtypes: intrahepatic, perihilar, and distal extrahepatic.

BTC shows differences in etiology, prevalence, and molecular alterations between Caucasian and Asian populations. BTC is relatively rare in Europe and the USA. Ageadjusted rates of CCC are reportedly lowest in non-Hispanic white people and black people (both 2.1 per 100,000) and highest in Hispanic and Asian populations (2.8-3.3 per 100,000). ${ }^{1,2}$ The highest rates are found in Eastern Asia especially the northeast of Thailand ( 85 per 100,000) ${ }^{3}$ whereas rates are low in South, Central, and Western Asia, as well as in Northern and Eastern Europe. ${ }^{4}$ The National Cancer Institute in Thailand estimated that liver and bile duct cancers were the most common cancers in men, with an estimated 8,000 new cases per year; the highest incidence was found in Khon Kaen, north-eastern region of Thailand. ${ }^{5}$

The etiology of CCC in Asian countries is liver fluke infestation especially Opisthorchis viverrini and Clonorchis sinensis. It induced chronic inflammation leading to oxidative DNA damage of the biliary epithelium and malignant transformation. 
C. sinensis infestation is common in rural area of Korea and China, whereas $O$. viverrini infestation is highly prevalent in the northeast of Thailand. ${ }^{6}$

Thailand has the highest incidence of intrahepatic CCC in the world, perhaps related to a tradition of eating raw fish, which may be contaminated with $O$. viverrini. $^{7}$

Although surgery is the only curative treatment for CCC, the resection rate is quite low and variable, as most patients present with advanced disease. Median survival after CCC resection is $10-40$ months. Patients with locally advanced or metastatic BTC have poor prognoses, with 5-year survival rates of $5 \%-10 \% .{ }^{8}$ The response rate (RR) of first-line systemic chemotherapy (gemcitabine- or 5-fluorouracil [5-FU]-based regimens) is $10 \%-40 \% .{ }^{9}$ Patients who received single-agent gemcitabine had median overall survival (mOS) of 6.5-11.5 months, ${ }^{10,11}$ whereas patients treated with 5-FU/leucovorin (LV) had mOS of 6-6.5 months. ${ }^{12-14}$ For patients who received combined 5-FU and cisplatin, mOS was 9.5-10 months. ${ }^{15-17}$ The other gemcitabine combination regimen was studied in a Phase II trial that showed an RR of $9 \%-36 \%$ and mOS of $11-15.4$ months. In addition, a Phase III randomized study (ABC-02) showed longer overall survival (OS) from gemcitabine/cisplatin over gemcitabine alone and led to this combined regimen becoming a standard first-line treatment. ${ }^{18}$ However, survival of patients with advanced disease remains poor with the current treatments. ${ }^{19}$

In the era of individualized medicine and targeted therapy, the molecular pathogenesis of CCC is worthy of study. Established mutations and amplification of known oncogenes had been shown in previous studies, including various molecular differences between Caucasian and Asian populations; for example, $8 \%-22 \%$ of Caucasians with CCC showed $B R A F$ mutations, whereas no $B R A F$ mutations were seen in Asian patients, who had higher rates of KRAS and $P I K 3 C A$ mutations and ROS1 gene rearrangements; however, EGFR mutation rates were similar in Asian and Caucasian patients $(14 \%-17 \%){ }^{20-38}$

In our previous pilot study by Detarkom, ${ }^{39}$ we found that some clinical prognostic factors affected survival, including staging, Eastern Cooperative Oncology Group (ECOG) performance status, surgical resection, and carbohydrate antigen 19-9 (CA19-9) pretreatment level. The study showed a trend of better OS in a patient with strong ALK expression, but due to the shortage of tissue sample, fluorescent in situ hybridization (FISH) for ALK could not be performed. Therefore, in this study, we explored clinical factors more extensively to predict prognosis and further studied genomic alteration in $\mathrm{CCC}$ in Thai patients with an aim to develop new treatment for this lethal disease.

\section{Materials and methods Study cohort, data, and clinical characteristics}

This study used a computerized search of the tumor registry database of Ramathibodi Hospital for patients treated from November 2007 to December 2013. The data were accessed using the International Classification of Disease-10 (ICD-10) and the database from the tumor bank of the Pathology Department. We selected patients who had been diagnosed with BTC, and from whom adequate tumor tissue for extracting DNA was available. We fully reviewed their medical records, with particular regard to the natural history of their disease including clinical and tumor characteristics (age, sex, smoking status, staging, tumor type, presenting symptoms, CA19-9 and carcinoma embryonic antigen [CEA] levels at diagnosis, viral hepatitis B surface antigen [HBsAg], and antihepatitis $\mathrm{C}$ virus [HCV] status, patient's birthplace, resection procedure, lymph node status, and medical treatment).

This study was approved by the ethics committee of Ramathibodi Hospital, Mahidol University, Bangkok, Thailand (EC approval number 11-56-03). As data collection and further analyses were performed without disclosure of the identity and private information of patients, informed consents for the review of medical records and the use of archived tissue samples were not required by the ethics committee of Ramathibodi Hospital.

We categorized tumor into 2 groups (intrahepatic and hilar/extrahepatic/gallbladder) by Bismuth classification that defines intrahepatic as a tumor that is located in intrahepatic bile duct, hilar type is located from common hepatic duct to position of cystic duct, extrahepatic is located at common bile duct to ampulla of Vater, and gallbladder type is tumor located at gallbladder and cystic duct.

Age at diagnosis was divided into 4 ranges: $\leq 50,51-60$, $61-70$, or $\geq 71$ years. Staging of disease was performed by using American Joint Committee on Cancer (AJCC) TNM staging system (seventh edition, 2010) according to the diagnosis.

Performance status was evaluated by ECOG scale and criteria. ECOG criteria was defined as follows: $0=$ fully active, able to carry on all pre-disease performance without restriction; $1=$ restricted in physically strenuous activity but ambulatory and able to carry out work of a light or sedentary nature, eg, light house work, office work; $2=$ ambulatory and capable of all self-care but unable to carry out any work activities. Up and about more than $50 \%$ of waking hours; $3=$ capable of only limited self-care, confined to bed or chair more than $50 \%$ of waking hours; $4=$ completely disabled, cannot carry on any self-care. Totally confined to bed or 
chair; $5=$ death. We grouped patients into 2 groups as ECOG $0-1$ and ECOG 2-4 for analyzing the data.

Presenting symptoms were categorized into 2 categories: asymptomatic or symptomatic with any symptoms (gastrointestinal-related symptoms and other symptoms that were not related to gastrointestine, eg, weight loss, back pain, and dyspnea).

Surgery was categorized into curative, diagnostic, or palliative procedure. Two categories of systemic chemotherapy were gemcitabine-based regimen (gemcitabine single agent, gemcitabine with cisplatin, and gemcitabine with carboplatin) or non-gemcitabine-based regimen (capecitabine, or 5-FU with LV). Lymph node status was obtained by pathological report from surgical specimen. $\mathrm{HCV}$ infection was evaluated by enzyme immunoassay to detect $\mathrm{HCV}$ antibodies. Hepatitis B virus (HBV) infection was evaluated by enzyme-linked immunosorbent assay (ELISA) to detect HBsAg. Blood for CA19-9\& CEA was collected at the time of first visit. Regarding hometown, patients from northern and north-eastern part of Thailand were analyzed compared with those who came from central, western, and southern part of Thailand, because north and north-eastern part of Thailand has highest incident rate of CCC. The result of treatment was assessed at the time after complete treatment with surgery, radiation therapy, or chemotherapy by clinical or radiological examination with Response Evaluation Criteria In Solid Tumors (RECIST) criteria.

Molecular alterations study: formalin-fixed, paraffinembedded (FFPE) tissue blocks from our archives, with tumor cellularity $\geq 50 \%$, were routinely prepared by a pathologist at the Department of Pathology, Faculty of Medicine Ramathibodi Hospital, Mahidol University. This study was approved by the research ethics committee of Faculty of Medicine Ramathibodi Hospital, Mahidol University (approval ID 11-56-03).

We randomly selected 81 FFPE tissue blocks from the years 2010-2013 and prepared them for ALK, HER2, and Ki-67 immunohistochemistry (IHC) staining. Molecular testing for mutations in KRAS, BRAF, EGFR, and PIK3CA from DNA extractions and RNA extractions was performed for FISH (only for ALK+ samples), and ROS1 translocation tests.

\section{Molecular testing for PIK3CA, BRAF, KRAS, and EGFR mutations}

Paraffin-embedded tissue was dissolved in xylene and followed by 2 washes with $100 \%$ ethanol to remove residual xylene. Tissue was digested at $56^{\circ} \mathrm{C}$ for 1 hour, then at $90^{\circ} \mathrm{C}$
1 hour, with $180 \mu \mathrm{L}$ of ATL buffer and $20 \mu \mathrm{L}$ of proteinase K. After digestion, $200 \mu \mathrm{L}$ of alkaline lysis (AL) buffer was added. The solution was transferred into a spin column and washed with the wash buffers provided in the QIAamp DNA Mini Kit (Qiagen, Hilden, Germany). The DNA was eluted in $30 \mu \mathrm{L}$ of ATE buffer and was ready for use in amplification reactions or for storage at $-20^{\circ} \mathrm{C}$.

\section{PIK3CA, BRAF, KRAS, and EGFR mutation testing by amplification-refractory mutation system-based quantitative polymerase chain reaction (ARMS-qPCR)}

DNA samples were subjected to PIK3CA, BRAF, KRAS, and EGFR mutant analysis using AmoyDx PIK3CA 5 Mutations, BRAF V600 Mutations, KRAS 7 Mutations, and $E G F R$ 29 Mutations Detection Kits (Amoy Diagnostics, Xiamen, China). These kits employ ARMS-real-time (RT) PCR technology to detect 5 common mutations in the PIK3CA gene, $V 600$ mutation in the BRAF gene, 7 mutations in KRAS codons 12 and 13, and 29 mutations in EGFR gene (Table S1). The experiments and analyses were performed according to the manufacturer's instructions, using Bio-Rad CFX96 RT-PCR (Bio-Rad Laboratories Inc., Hercules, CA, USA).

\section{Sanger sequencing for EGFR mutations}

We assembled 10 ng DNA with $10 \mu \mathrm{L}$ AmpliTaq Gold ${ }^{\mathbb{B}}$ PCR Master Mix (Thermo Fisher Scientific, Waltham, MA, USA) and $10 \mu \mathrm{M}$ forward and reverse $E G F R$-specific primers (Table S2). PCRs were amplified, and the PCR product was then purified. Sequencing reactions were performed using chain-terminating dideoxynucleotides $\left(\mathrm{BigDye}^{\circledR} 1.0\right.$; Thermo Fisher Scientific) and loaded into an automated ABI 310 sequencer. Eventually, the data were analyzed by Sequencer 3.1.1 Software (Thermo Fisher Scientific).

\section{Droplet digital PCR (ddPCR) for EGFR mutations}

ddPCR reagents were ordered from Bio-Rad Laboratories Inc. Combined nucleic DNA and primer/probe mixes for EGFR T790M were custom made by Thermo Fisher Scientific. PCRs were performed from a DNA template, $1 \times$ ddPCR Mastermix (Bio-Rad Laboratories Inc.), TaqMan probe, and $20 \times$ custom primers made specifically for each assay. Each ddPCR mix was loaded into the wells of a droplet generator cartridge (Bio-Rad Laboratories Inc.). The target DNA and background DNA were randomly distributed in droplets, which were transferred to a 96-well PCR plate. The plate was sealed and subjected to the PCR protocol. The 96-well PCR 
plate was loaded into the QX-100 droplet reader (Bio-Rad Laboratories Inc.). Data were read and analyzed by QuantaSoft analysis software (Bio-Rad Laboratories Inc.).

\section{ROSI translocation testing by RT-PCR}

Paraffin was removed from FFPE tissue sections by treatment with xylene. Samples were incubated at $56^{\circ} \mathrm{C}$ for $15 \mathrm{~min}$; then, at $80^{\circ} \mathrm{C}$ for $15 \mathrm{~min}$ with lysis buffer, which contained proteinase $\mathrm{K}$, treat lysate with DNase was then mixed with buffer red blood cell and ethanol. The solution was applied to an RNeasy MinElute spin column. RNA was eluted into $14 \mu \mathrm{L}$ of RNase-free water and was ready for use or for storage at $-80^{\circ} \mathrm{C}$.

We evaluated FFPE tumor samples for ROS1 fusion using the AmoyDxROS1 Gene Fusions Detection Kit (Amoy Diagnostics). About $50 \mathrm{ng} / \mathrm{mL}$ of RNA OD260/OD280 value (1.9-2.0 of RNA) sample was used for reverse transcription and RT-PCR of 4 reactions of ROS1 Fusion Gene Detection Kit according to the manufacturer's instruction. This kit detected 14 ROS1 gene fusions with various spliced genes and exons. We analyzed reaction sample reference gene $\mathrm{Ct}$ value $\leq 20$. If sample 6-carboxyfluorescein (FAM) $\mathrm{Ct}$ value was $<30$, the sample was considered positive for one of the variants detected by reaction mixture.

\section{IHC staining}

All IHC staining was performed on $4 \mu \mathrm{m}$-thick FFPE tissue sections. The slides were deparaffinized, and antigen retrieval was performed. We identified ALK, HER2, and Ki-67 expression by IHC using D5F3, HER2/neu, and Ki-67 antibodies, respectively, on the sections. For ALK, FFPE tissues were sectioned at $4 \mu \mathrm{m}$ thickness and stained with anti-ALK rabbit monoclonal antibody (clone D5F3; 1:20 dilution; Ventana Medical Systems, Tucson, AZ, USA), using the Optiview DAB IHC Detection Kit and Optiview Amplification Kit with the Ventana Benchmark XT Stainer (Ventana Medical Systems) according to the manufacturer's protocol. Immunoreactivity was scored as follows: 0, no staining; $1+$, faint cytoplasmic staining; $2+$, moderate cytoplasmic staining; $3+$, strong granular cytoplasmic staining in $\geq 10 \%$ of tumor cells. Immunoreactivity was evaluated as positive or negative according to the manufacturer's protocol. If the specimen had positive IHC staining for ALK, we then performed FISH to confirm $A L K$ rearrangement.

Tissue sections were IHC stained for HER2 on BenchMark XT IHC/ISH staining module (Ventana Medical Systems), using the technical protocol XT UltraView DAB V3 by incubation with anti-HER2/neu (4B5) rabbit monoclonal primary antibody. Antigen detection was carried out using
UltraView Universal DAB IHC Detection Kit (Ventana Medical Systems). IHC staining was assessed and scored by a pathologist. HER 2 expression scores of 0 and $1+$ were considered to be HER 2 negative, and $2+$ and $3+$ as HER 2 positive. A standard criterion for HER2 scoring was utilized. ${ }^{40}$

Tissue sections were IHC stained for Ki-67 on a BenchMark XT IHC/ISH staining module (Ventana Medical Systems) using the technical protocol XT Ultra View DAB V3 by incubation with Confirm anti-Ki-67 (30-9) rabbit monoclonal primary antibody. Antigen detection was carried out using UltraView Universal DAB IHC Detection Kit. IHC staining was assessed and scored by a pathologist. The labeling index of the Ki-67 in each tumor was estimated as a percentage of positive cells out of 100-1,000 counted tumor cells.

\section{Statistical analysis}

Statistical analyses were performed using STATA software v.13 (StataCorp LP, College Station, TX, USA). OS and progression-free survival (PFS) were calculated and censored on January 31, 2015. OS and PFS curves were drawn using the Kaplan-Meier method. The log-rank test was used to compare survival rates by each variable. Univariate analysis of OS and PFS used the Cox proportional hazards regression model. Significantly, prognostic factors were included in subsequent multivariate analyses. $P \leq 0.05$ was considered significant. The correlation between molecular alteration and survival was compared by log-rank test. Mean Ki-67 in each molecular alteration group was compared by the Mann-Whitney $U$ test.

\section{Results EGFR mutation}

We found that 17 out of 81 samples $(21 \%)$ were positive for EGFR mutations, comprising 9 with $T 790 M$, 4 with $S 768 I, 2$ with $L 861 Q$, 1 with $G 719 X$, and 1 with insertion (Table 1). The $E G F R^{+}$group showed a nonsignificant trend of longer

Table I Molecular alteration in CCC

\begin{tabular}{lll}
\hline Gene & Positive samples & $\%$ \\
\hline EGFR mutation & 17 in 8 I & 21 \\
T790M & 9 in I7 & 53 \\
S768I & 4 in I7 & 24 \\
L86IQ & 2 in I7 & 12 \\
G7I9X & $I$ in I7 & 6 \\
Exon 20 insertion & 1 in I7 & 6 \\
KRAS mutation & 10 in 8 I & 12 \\
BRAF mutation & 0 in 81 & 0 \\
PIK3CA mutation & 13 in 81 & 16 \\
ROSI translocation & 0 in 81 & 0 \\
ALK expression & 0 in 74 & 0 \\
HER2 expression & 3 in 74 & 4 \\
Ki-67 expression & 74 in 74 & Range 4\%-85\% \\
\hline
\end{tabular}

Abbreviation: CCC, cholangiocarcinoma. 
mOS than the $E G F R^{-}$group (7.92 vs 11.52 months, $\left.P=0.927\right)$ (Table 2 and Figure 1A). Median PFS (mPFS) was comparable between the $E G F R^{M u t+}$ and $E G F R^{M u t-}$ groups (6.45 vs 7.60 months, $P=0.724$; Table 2 and Figure 2A). Patients with $T 790 M^{\mathrm{Mut+}}$ mutations group showed a nonsignificant trend of longer mOS (18.84 vs 11.52 months, $P=0.199)$ and mPFS ( 10.15 vs 7.60 months, $P=0.371$; Table 2 and Figures $1 \mathrm{~B}$ and $2 \mathrm{~B}$ ) than the $E G F R^{\text {Mut- }}$ group. However, patients with $T 790 M$ mutations had a significant longer mOS (18.84 months) than the non-T790M mutation group (4.08 months, $P=0.038$; Table 2 and Figure 1C); the $T 790 M$ group also had a trend of longer mPFS (10.15 vs 3.63 month, 0.063; Table 2 and Figure 2C).

We further validated the positive results of $E G F R^{M u t+}$ mutation results by the Sanger direct sequencing method which is a gold standard method for mutation analysis, and by ddPCR, which is a highly sensitive method for detecting low percentages of gene mutations $(0.1 \%-5 \%$ of gene frequency) compared with ARMS-qPCR ( $1 \%-5 \%$ of frequency). ${ }^{41}$ We found $100 \%$ concordance of EGFR T790M mutation by ddPCR, compared with qRT-PCR, but only 5 of 9 (55.55\%) T790M mutations were detected by direct sequencing (Table 3 and Figure 3 ). We did not confirm exon 20 insertion and $L 861 Q$ in ddPCR, because we did not have enough DNA. However, we confirmed $L 861 Q$ with Sanger direct sequencing, but unfortunately we did not find it.

\section{PIK3CA mutation}

In 81 samples, 13 (16\%) were positive for PIK3CA mutations (PIK3CA $\left.A^{M u t+}\right)$, which comprised 6 with $E 545 K, 3$ with $E 542 K$, 3 with $H 1047 R$, and 1 with double mutations of $E 542 K$ and E545K (Table 1). The PIK3CA ${ }^{M u t+}$ had a trend of longer mOS than the $P I K 3 C A^{\text {Mut }}$ group (18.84 vs 7.56 months, $\left.P=0.072\right)$ and significantly longer mPFS than the PIK3CA $A^{\text {Mut }}$ group (15.87 vs 7.01 months, $P=0.043$; Table 2 and Figures 1D and 2D).

\section{KRAS mutation, BRAF mutation, and ROSI translocation}

We found that 10 out of the 81 samples $(12 \%)$ were positive for KRAS mutation (KRAS $S^{M u t+}$ ), comprising 2 with G12Asp, 1 with G12Ala, 3 with $12 \mathrm{~V}, 1$ with G12S, 1 with G13Asp, and 1 with double mutations of G12Asp and G12 (Table 1). The $K R A S^{M u t+}$ and $K R A S^{\text {Mut- }}$ groups did not significantly differ in mOS or mPFS at $P<0.05$ (Table 2 and Figures $1 \mathrm{E}$ and $2 \mathrm{E}$ ). We detected no BRAF mutation or ROS1 translocation in the 81 samples (Table 1 ).

\section{Clinical characteristics and prognostic factors based on significant gene alterations}

The clinical characteristics and clinical data categorized based on each molecular alterations (EGFR, EGFR T790M, $P I K 3 C A$, and KRAS) of CCC patients were similar as listed in Table 4, except staging that was significantly different based on KRAS mutation and CEA baseline level at cut point of $15 \mu \mathrm{g} / \mathrm{L}$ was significantly different based on PIK3CA mutation.

\section{IHC}

Not all 81 patients were tested for ALK expression due to the exhaustion of tumor tissue. We tested 74 samples for ALK expression, all of which showed negative ALK expression (Table 1). We found strongly positive staining (IHC $2+$ and $3+$ ) for HER2 expression in 3 out of 74 (4\%) samples.

Table 2 OS and PFS of CCC by molecular analysis $(\mathrm{N}=8 \mathrm{I})$

\begin{tabular}{|c|c|c|c|c|c|c|c|}
\hline Molecular analysis & $\begin{array}{l}\text { Patients, } \\
\text { n (\%) }\end{array}$ & $\begin{array}{l}\text { mPFS } \\
\text { (months) }\end{array}$ & HR $(95 \% \mathrm{CI})$ & $P$-value & $\begin{array}{l}\text { mOS } \\
\text { (months) }\end{array}$ & HR (95\% Cl) & $P$-value \\
\hline \multicolumn{8}{|l|}{ EGFR mutation $(\mathrm{N}=8 \mathrm{I})$} \\
\hline Negative (reference) & $64(79)$ & 7.60 & I.II (0.62-2.00) & 0.724 & 11.52 & $0.97(0.51-1.82)$ & 0.927 \\
\hline Positive & $17(21)$ & 6.45 & & & 7.92 & & \\
\hline \multicolumn{8}{|c|}{ EGFR mutation $(T 790 M)(\mathrm{N}=73)$} \\
\hline Negative (reference) & $64(88)$ & 7.60 & $0.68(0.29-1.58)$ & 0.371 & 11.52 & $0.55(0.22-1.37)$ & 0.199 \\
\hline T790M & $9(12)$ & 10.15 & & & 18.84 & & \\
\hline \multicolumn{8}{|c|}{ EGFR mutation $(T 790 M)(\mathrm{N}=17)$} \\
\hline Non-T790M (reference) & $8(47)$ & 3.63 & $0.34(0.11-1.06)$ & 0.063 & 4.08 & $0.26(0.08-0.93)$ & 0.038 \\
\hline T790M & $9(53)$ & 10.15 & & & 18.84 & & \\
\hline \multicolumn{8}{|l|}{ PIK3CA mutation $(\mathrm{N}=8 \mathrm{I})$} \\
\hline Negative (reference) & $68(84)$ & 7.01 & $0.46(0.22-0.98)$ & 0.043 & 7.56 & $0.50(0.24-1.06)$ & 0.072 \\
\hline Positive & $13(16)$ & 15.87 & & & 18.84 & & \\
\hline \multicolumn{8}{|l|}{ KRAS mutation $(\mathrm{N}=8 \mathrm{I})$} \\
\hline Negative (reference) & $71(88)$ & 7.60 & $1.18(0.58-2.38)$ & 0.643 & 9.24 & $1.07(0.52-2.26)$ & 0.847 \\
\hline Positive & $10(12)$ & 7.01 & & & 9.36 & & \\
\hline
\end{tabular}

Abbreviations: CCC, cholangiocarcinoma; HR, hazard ratio; mOS, median OS; mPFS, median PFS; OS, overall survival; PFS, progression-free survival. 


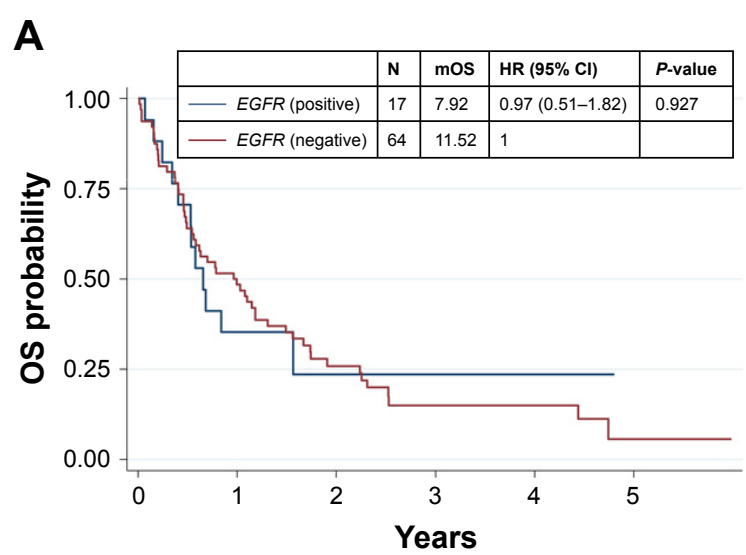

\section{OS}

C
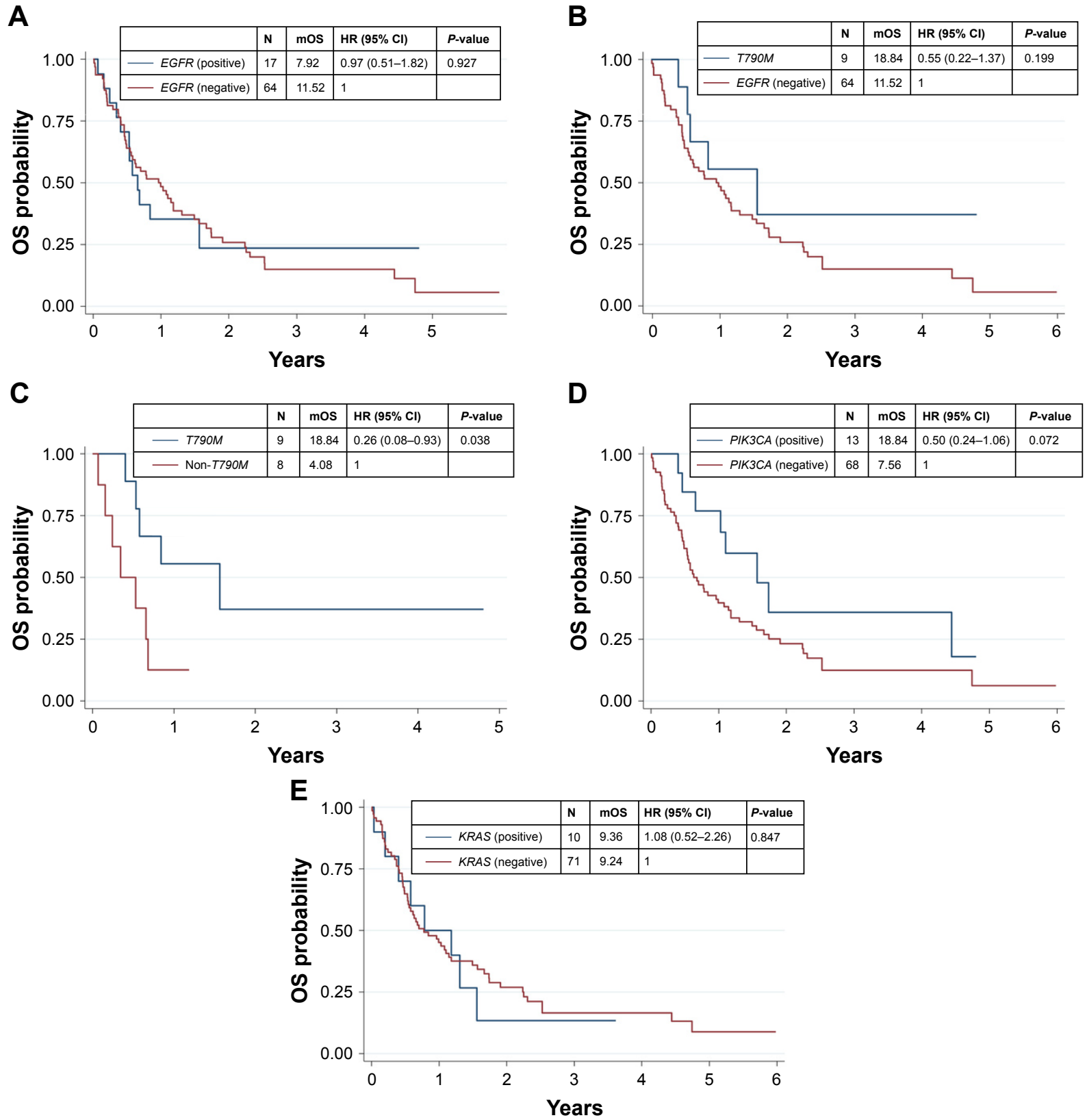

Figure I Kaplan-Meier curve for OS of CCC according to gene alteration.

Notes: (A) OS by EGFR mutation. (B) OS by EGFR T790M mutation and negative EGFR mutation. (C) OS by EGFR T790M mutation and other positive EGFR mutation. (D) OS by PIK3CA mutation. (E) OS by KRAS mutation.

Abbreviations: CCC, cholangiocarcinoma; HR, hazard ratio; mOS, median OS; OS, overall survival.

Another 9 samples had IHC 1+ staining for HER2 (Table 1). Median Ki-67 was $42.5 \%$ (interquartile range: $4 \%-85 \%$ ). The EGFR $R^{M u t+}$ and $E G F R^{M u t-}$ groups did not significantly differ in median Ki-67 ( $65 \%$ vs $40 \%, P=0.121$ ). However, T790M samples had a significantly lower median Ki-67 than did samples without $T 790 M$ mutations ( $22.5 \%$ vs $80 \%$, $P=0.025)$. The $P I K 3 C A^{M u t+}$ group had lower median Ki-67 but not significantly so ( $25 \%$ and $47.5 \%, P=0.273)$. The $K R A S^{M u t+}$ and $K R A S^{\text {Mut }}$ groups did not significantly differ in median Ki-67 (22.5\% vs 45\%, $P=0.260$; Table 5).

\section{Discussion}

CCC is a lethal malignancy that usually presents at an advanced stage. Due to the difficulty of early diagnosis and limited effective treatment, $\mathrm{CCC}$ has a poor prognosis. Few new treatments seem to be in development or in trials, 

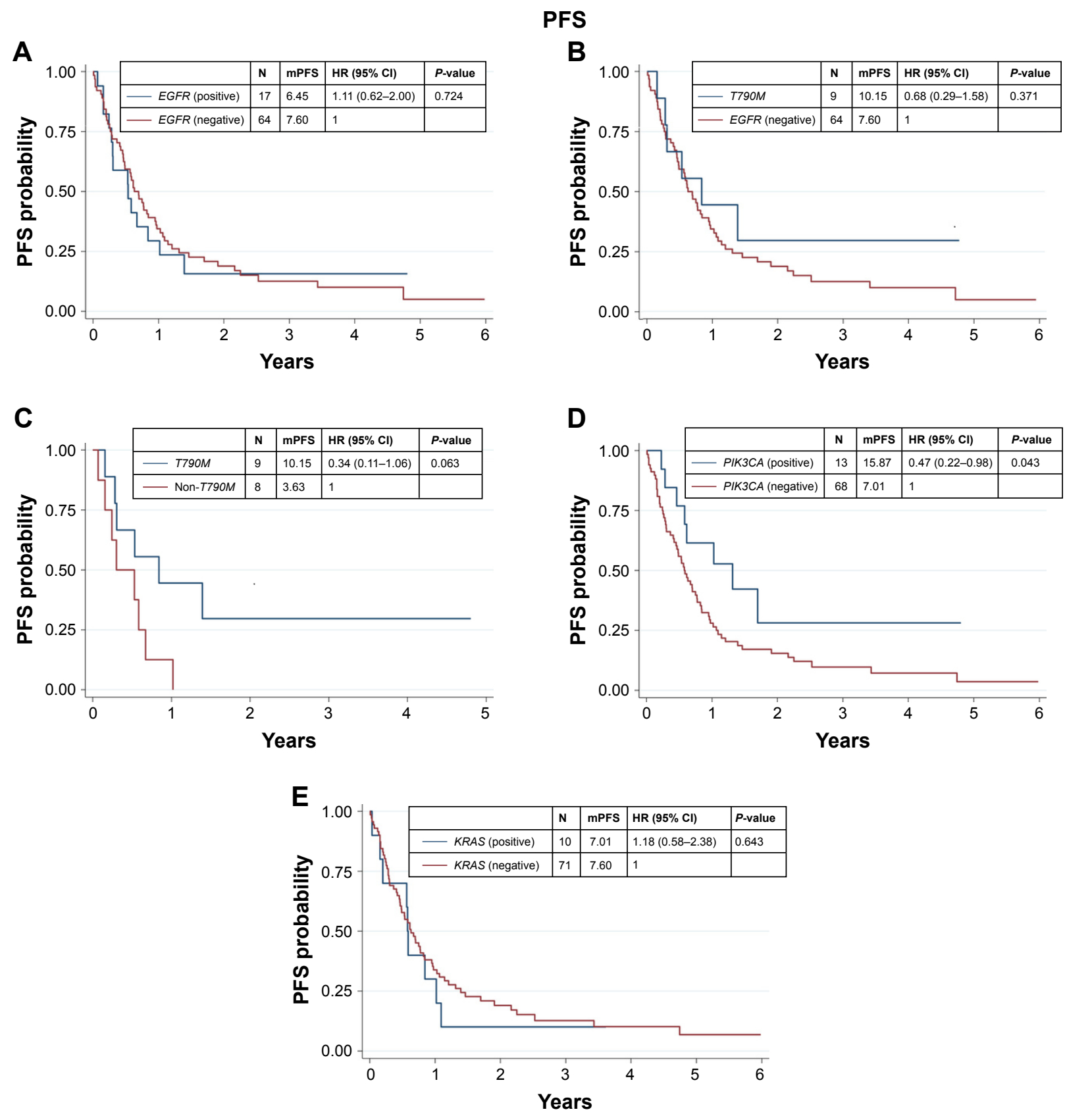

Figure 2 Kaplan-Meier curve for PFS of CCC according to gene alteration.

Notes: (A) PFS by EGFR mutation. (B) PFS by EGFR T790M mutation and negative EGFR mutation. (C) PFS by EGFR T790M mutation and other positive EGFR mutation. (D) PFS by PIK3CA mutation. (E) PFS by KRAS mutation.

Abbreviations: CCC, cholangiocarcinoma; HR, hazard ratio; mPFS, median PFS; PFS, progressive-free survival.

because of the lack of clinical data and oncogenic data. However, as most relevant studies show differences in clinical characteristics and genetic alterations in Western and Asian populations, we have therefore investigated the clinical data and genomic alterations in Thai patients.

In our study, we found $21 \%$ of Thai patients with CCC had $E G F R^{\text {Mut }}$ tumor tissues, which was higher than that seen in other populations investigated in previous studies. . $22,42-44^{-1}$
Types of EGFR mutation included 1 case in exon 18 (G719X), 13 cases in exon 20 ( 9 of T790M, 4 of $S 768 I$ ), and 3 cases in exon 21 ( 2 of $L 861 Q$ and 1 of insertion). Consistent with a Taiwan study, ${ }^{43}$ no exon 19 mutation was identified, but contrast to Italian study, ${ }^{42}$ which found an exon 19 substitution $(K 757 R)$ in 1 out of 40 samples. Interestingly, we found a high rate of $T 790 M$ mutation (50\% of EGFR mutation), and this group had significant longer OS and a trend of longer 
Table 3 Detection of EGFR mutation by qRT-PCR, Sanger sequencing, and $d d P C R$

\begin{tabular}{llll}
\hline EGFR mutation & qRT-PCR & $\begin{array}{l}\text { Sanger } \\
\text { sequencing }\end{array}$ & ddPCR \\
\hline EGFR & 17 & 7 & 14 \\
T790M & 9 & 5 & 9 \\
S768I & 4 & 2 & 4 \\
L86IQ & 2 & $\mathrm{ND}$ & $\mathrm{NA}$ \\
G7I9X & $\mathrm{I}$ & $\mathrm{ND}$ & $\mathrm{I}$ \\
Exon 20 insertion & $\mathrm{I}$ & $\mathrm{NA}$ & $\mathrm{NA}$ \\
\hline
\end{tabular}

Abbreviations: $d d P C R$, droplet digital polymerase chain reaction; NA, not available; ND, not determined; qRT-PCR, quantitative real-time polymerase chain reaction.

PFS than did the non-T790M group. However, the study by Chang et $\mathrm{al}^{43}$ reported EGFR mutation to be the strongest independent predictor of shorter OS. In addition to longer survival, patients with the $T 790 M$ mutation in our study also had a significant lower median Ki-67 compared with the non-T790M group - interestingly, as we know that Ki-67 indicates cell proliferation.
To our knowledge, no study has previously reported this correlation between $7790 \mathrm{M}$ mutation and clinicopathological factors or prognosis in patients with $\mathrm{CCC}$.

Approximately $12 \%$ of patients had $K R A S$ mutations, most of which were located in codon 12 and only 1 in codon 13 . One of the previous studies reported $16 \%$ of KRAS mutation in codon 12 in Thai population. ${ }^{45}$ Other populations have shown a reported $13 \%-50 \%$ prevalence of $K R A S$ mutations in BTCs. ${ }^{22,36,37,43,46} B R A F$ mutation was not detected in this study, which was similar to the report by $\mathrm{Xu}$ et $\mathrm{al}^{36}$ in a Chinese population, whereas Tannapfel et $\mathrm{al}^{22}$ demonstrated $22 \%(15 / 69)$ had positive $B R A F$ mutations but found no significant correlation with the other clinicopathological factors and patient survival. We could not find the ROS1 translocation in our Thai CCC cohort, although a 2011 study found $8.7 \%$ of $R O S 1$ translocations in an Asian population. ${ }^{35}$

$P I K 3 C A$ mutation was rare in a previous study; Riener et $\mathrm{al}^{47}$ reportedly found it in only 1 out of $11(9 \%)$ intrahepatic CCC samples and 1 out of $23(4 \%)$ in gallbladder carcinoma samples.
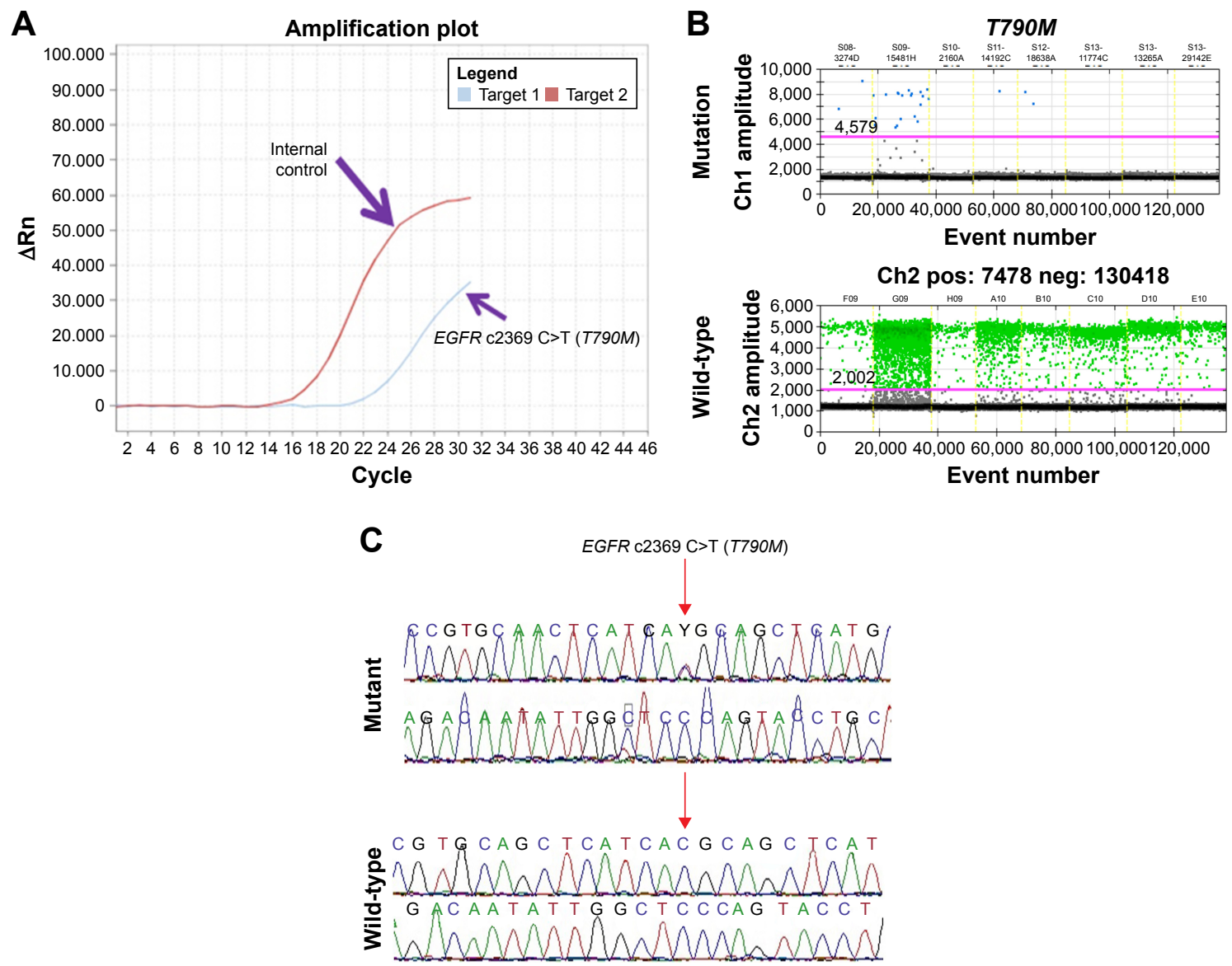

Figure 3 Analysis of EGFR T790M mutation using RT-PCR, ddPCR, and Sanger sequencing.

Notes: (A) Amplification curve of sample with EGFR c2369 C > T (T790M) mutation (blue line) and internal control (red line). (B) ddPCR amplitude scatter plot, single-well data for wild-type DNA; mutation assay (FAM, channel I), wild-type assay (Hex, channel 2). (C) Chromatograms EGFR c2369 C>T (T790M).

Abbreviations: ChI, channel I; Ch2, channel 2; ddPCR, droplet digital polymerase chain reaction; FAM, 6-carboxyfluorescein; Hex, hexachloro-6-carboxyfluorescein; neg, negative; pos, positive; RT-PCR, real-time polymerase chain reaction. 
Table 4 Demographic and clinical characteristics of patients categorized by mutations

\begin{tabular}{|c|c|c|c|c|c|c|c|c|c|c|c|c|}
\hline \multirow[t]{2}{*}{ Characteristic } & \multicolumn{2}{|c|}{ EGFR mutation } & \multirow[t]{2}{*}{$P$-value } & \multicolumn{2}{|c|}{ EGFR T790M } & \multirow[t]{2}{*}{$P$-value } & \multicolumn{2}{|c|}{ PIKЗCA mutation } & \multirow[t]{2}{*}{$P$-value } & \multicolumn{2}{|c|}{ KRAS mutation } & \multirow[t]{2}{*}{$P$-value } \\
\hline & Positive & Negative & & T790M & $\begin{array}{l}\text { Non- } \\
\text { T790M }\end{array}$ & & Positive & Negative & & Positive & Negative & \\
\hline \multicolumn{13}{|l|}{ Age, years $(\mathrm{N}=8 \mathrm{I})$} \\
\hline$\leq 50$ & $3(3.70)$ & $8(9.88)$ & 0.733 & $2(11.77)$ & I (5.88) & 0.430 & $3(3.70)$ & $8(9.88)$ & 0.710 & $2(2.47)$ & $9(11.11)$ & 0.572 \\
\hline $51-60$ & $6(7.4 I)$ & $24(29.63)$ & & $4(23.53)$ & $2(11.77)$ & & $4(4.92)$ & $26(32.10)$ & & $2(2.47)$ & $28(34.57)$ & \\
\hline $6 I-70$ & $7(8.64)$ & $22(27.16)$ & & $2(11.77)$ & $5(29.4 I)$ & & $4(4.92)$ & $25(30.86)$ & & $4(4.92)$ & $25(30.86)$ & \\
\hline$\geq 71$ & $\mathrm{I}(\mathrm{I} .23)$ & $10(12.35)$ & & I (5.88) & $0(0)$ & & $2(2.47)$ & $9(11.11)$ & & $2(2.47)$ & $9(I I . I I)$ & \\
\hline \multicolumn{13}{|c|}{ ECOG performance status $(\mathrm{N}=8 \mathrm{I})$} \\
\hline $0-1$ & $16(19.75)$ & $58(71.6 I)$ & 1.000 & $9(52.94)$ & $7(4|| 8)$. & 0.471 & $13(16.05)$ & $6 I(75.31)$ & 0.591 & $8(9.88)$ & $66(8 I .48)$ & 0.206 \\
\hline $2-4$ & $\mathrm{I}(\mathrm{I} .23)$ & $6(7.4 I)$ & & $0(0)$ & I (5.88) & & $0(0)$ & $7(8.64)$ & & $2(2.47)$ & $5(6.17)$ & \\
\hline \multicolumn{13}{|l|}{$\operatorname{Sex}(N=8 I)$} \\
\hline Male & $6(7.4 I)$ & $39(48.15)$ & 0.059 & $2(11.77)$ & $4(23.53)$ & 0.335 & $8(9.88)$ & $37(45.68)$ & 0.636 & $5(6.17)$ & 31 (38.27) & 0.745 \\
\hline Female & II (13.58) & $25(30.86)$ & & $7(41.18)$ & $4(23.53)$ & & $5(6.17)$ & $31(38.27)$ & & $5(6.17)$ & $40(49.38)$ & \\
\hline \multicolumn{13}{|l|}{ Type $(\mathrm{N}=8 \mathrm{I})$} \\
\hline Intrahepatic & $15(18.52)$ & $62(96.88)$ & 0.192 & $7(41.18)$ & $8(47.06)$ & 0.471 & $12(14.8 \mathrm{I})$ & $65(80.25)$ & 0.511 & $9(11.11)$ & $68(83.95)$ & 0.416 \\
\hline Extrahepatic + GB & $2(2.47)$ & $2(3.13)$ & & $2(11.77)$ & $0(0)$ & & I (I.24) & $3(3.70)$ & & I (I.24) & $3(3.70)$ & \\
\hline \multicolumn{13}{|c|}{ Lymph node status $(\mathrm{N}=5 \mathrm{I})$} \\
\hline Positive & $7(13.73)$ & $24(47.06)$ & 0.454 & $5(55.56)$ & $2(22.22)$ & 1.000 & $6(11.76)$ & $25(49.02)$ & 0.382 & $5(9.8)$ & $26(50.98)$ & 0.724 \\
\hline Negative & $2(3.92)$ & $18(35.29)$ & & $2(22.22)$ & $0(0)$ & & $6(11.76)$ & $14(27.45)$ & & $4(7.84)$ & $16(31.37)$ & \\
\hline \multicolumn{13}{|l|}{ Staging $(\mathrm{N}=8 \mathrm{I})$} \\
\hline I & $4(4.94)$ & $14(17.28)$ & 1.000 & $2(11.77)$ & $2(11.77)$ & 1.000 & $5(6.17)$ & $13(16.05)$ & 0.121 & $2(2.47)$ & $16(19.75)$ & 0.030 \\
\hline ॥ & I (I.24) & $6(7.4 I)$ & & I (5.88) & $0(0)$ & & I (I.24) & $6(7.4 I)$ & & $0(0)$ & $7(8.64)$ & \\
\hline III & $0(0)$ & $2(2.47)$ & & $0(0)$ & $0(0)$ & & I (I.24) & I (I.24) & & $2(2.47)$ & $0(0)$ & \\
\hline IV & $12(14.82)$ & $42(51.85)$ & & $6(35.29)$ & $6(35.29)$ & & $6(7.4 I)$ & $48(59.26)$ & & $6(7.4 I)$ & $48(59.26)$ & \\
\hline Smoking status $(\mathrm{N}=8 \mathrm{I})$ & & & & & & & & & & & & \\
\hline Current & $3(3.70)$ & $4(4.94)$ & 0.157 & $0(0)$ & $3(17.65)$ & 0.082 & I (I.24) & $6(7.4 I)$ & 1.000 & I (I.24) & $6(7.4 I)$ & 1.000 \\
\hline $\begin{array}{l}\text { No smoking/ } \\
\text { ex-smoker }\end{array}$ & $14(17.28)$ & $60(74.07)$ & & $9(54.24)$ & $5(29.4 I)$ & & $12(14.82)$ & $62(76.54)$ & & $9(11.11)$ & $65(80.25)$ & \\
\hline Group of symptoms ( & $\mathrm{N}=8 \mathrm{I}$ ) & & & & & & & & & & & \\
\hline Asymptomatic & $2(2.47)$ & $15(18.52)$ & 0.503 & $0(0)$ & $2(11.77)$ & 0.206 & $2(2.47)$ & $15(18.52)$ & 0.726 & I (I.24) & $16(19.75)$ & 0.680 \\
\hline Symptomatic & $15(18.52)$ & $49(79.01)$ & & $9(54.24)$ & $6(35.29)$ & & II (I3.58) & $53(65.43)$ & & $9(11.11)$ & $55(67.90)$ & \\
\hline Surgery $(\mathrm{N}=8 \mathrm{I})$ & & & & & & & & & & & & \\
\hline Yes & II (I3.58) & $44(54.32)$ & $0.75 \mathrm{I}$ & $8(47.06)$ & $3(17.65)$ & 0.050 & $12(14.82)$ & $43(53.09)$ & 0.052 & $9(11.11)$ & $46(56.79)$ & 0.156 \\
\hline No & $6(7.4 I)$ & $20(24.69)$ & & I (5.88) & $5(29.4 I)$ & & I (I.24) & $25(30.86)$ & & I (I.24) & $25(30.86)$ & \\
\hline Aim of surgery $(\mathrm{N}=55)$ & & & & & & & & & & & & \\
\hline Curative & $9(16.36)$ & $40(72.73)$ & 0.413 & $6(54.55)$ & $3(27.27)$ & 1.000 & II (20) & 38 (69.09) & 1.000 & $9(16.36)$ & $40(72.73)$ & 0.645 \\
\hline Diagnosis & $2(3.64)$ & $3(5.45)$ & & $2(18.18)$ & $0(0)$ & & $\mathrm{I}(\mathrm{I} .8 \mathrm{I})$ & $4(7.27)$ & & $0(0)$ & $5(9.09)$ & \\
\hline Palliative & $0(0)$ & I (I.82) & & $0(0)$ & $0(0)$ & & $0(0)$ & $\mathrm{I}(\mathrm{I} .8 \mathrm{I})$ & & $0(0)$ & $\mathrm{I}(\mathrm{I} .8 \mathrm{I})$ & \\
\hline Receive first-line syste & mic chemot & therapy $(\mathrm{N}=$ & $-81)$ & & & & & & & & & \\
\hline No & II (I3.58) & $40(49.38)$ & 0.867 & $6(35.29)$ & $5(29.4 I)$ & 1.000 & $8(9.88)$ & 43 (53.09) & 1.000 & 7 (8.64) & $44(54.32)$ & 0.737 \\
\hline Yes & $6(7.4 I)$ & $24(29.63)$ & & $3(17.65)$ & $3(17.65)$ & & $5(6.17)$ & $25(30.86)$ & & $3(3.70)$ & $27(33.33)$ & \\
\hline Regimen of systemic cl & hemotherap & py $(\mathrm{N}=3 \mathrm{I})$ & & & & & & & & & & \\
\hline Gemcitabine based & $6(19.35)$ & $22(70.97)$ & 1.000 & $3(50)$ & $3(50)$ & $\mathrm{N} / \mathrm{A}$ & $5(16.13)$ & $23(74.19)$ & 1.000 & $2(6.45)$ & $26(83.87)$ & $0.27 I$ \\
\hline $\begin{array}{l}\text { Non-gemcitabine } \\
\text { based }\end{array}$ & $0(0)$ & $3(9.68)$ & & $0(0)$ & $0(0)$ & & $0(0)$ & $3(9.68)$ & & I (3.23) & $2(6.45)$ & \\
\hline Site of metastases $(\mathrm{N}=$ & $=54)$ & & & & & & & & & & & \\
\hline$\leq 1$ & $9(16.67)$ & $35(64.8 I)$ & 0.674 & $5(4 I .67)$ & $4(33.33)$ & 1.000 & $5(9.26)$ & $39(72.22)$ & 1.000 & $6(11.11)$ & $38(70.37)$ & 0.580 \\
\hline$\geq 2$ & $3(5.56)$ & $7(12.96)$ & & I (8.33) & $2(16.67)$ & & I (I.85) & $9(16.67)$ & & $0(0)$ & $10(1.85)$ & \\
\hline $\mathrm{HBsAg}(\mathrm{N}=56)$ & & & & & & & & & & & & \\
\hline Positive & $3(5.36)$ & $9(16.07)$ & 1.000 & I (7.69) & $2(15.39)$ & 0.559 & I (I.79) & II (19.64) & $0.67 I$ & $2(3.57)$ & $10(17.86)$ & 0.635 \\
\hline Negative & $10(17.86)$ & $34(60.7 I)$ & & $6(46.15)$ & $4(30.77)$ & & $9(16.07)$ & $35(62.50)$ & & $5(8.93)$ & $39(69.64)$ & \\
\hline Anti-HCV (N=53) & & & & & & & & & & & & \\
\hline Positive & $0(0)$ & $0(0)$ & N/A & $0(0)$ & $0(0)$ & N/A & $0(0)$ & $0(0)$ & N/A & $0(0)$ & $0(0)$ & N/A \\
\hline Negative & $12(22.64)$ & $4 \mid(77.36)$ & & $6(50)$ & $6(50)$ & & $10(1.89)$ & $43(81.13)$ & & $6(11.32)$ & $47(88.68)$ & \\
\hline Birthplace $(\mathrm{N}=8 \mathrm{I})$ & & & & & & & & & & & & \\
\hline$N+N E$ & $8(9.88)$ & $28(34.57)$ & 0.807 & $3(17.65)$ & $5(29.4 I)$ & 0.347 & $5(6.17)$ & 31 (38.27) & 0.636 & $7(8.64)$ & $29(35.80)$ & 0.100 \\
\hline $\mathrm{C}+\mathrm{S}+\mathrm{W}$ & 9 (II.II) & $36(44.44)$ & & $6(35.29)$ & $3(17.65)$ & & $8(9.88)$ & $37(45.68)$ & & $3(3.70)$ & $42(5 \mid .85)$ & \\
\hline
\end{tabular}


Table 4 (Continued)

\begin{tabular}{|c|c|c|c|c|c|c|c|c|c|c|c|c|}
\hline \multirow[t]{2}{*}{ Characteristic } & \multicolumn{2}{|c|}{ EGFR mutation } & \multirow[t]{2}{*}{$P$-value } & \multicolumn{2}{|c|}{ EGFR T790M } & \multirow[t]{2}{*}{$P$-value } & \multicolumn{2}{|c|}{ PIKЗCA mutation } & \multirow[t]{2}{*}{$P$-value } & \multicolumn{2}{|c|}{ KRAS mutation } & \multirow[t]{2}{*}{$P$-valu } \\
\hline & Positive & Negative & & T790M & $\begin{array}{l}\text { Non- } \\
\text { T790M }\end{array}$ & & Positive & Negative & & Positive & Negative & \\
\hline \multicolumn{13}{|l|}{ CEA $(\mathrm{N}=68)$} \\
\hline$<15$ & 8 (II.77) & $4 I(60.29)$ & 0.727 & $4(33.33)$ & $4(33.33)$ & 0.576 & $13(19.12)$ & $36(52.94)$ & 0.014 & $7(10.29)$ & $42(61.76)$ & 1.000 \\
\hline$\geq 15$ & $4(5.88)$ & $15(22.06)$ & & $3(25.00)$ & I (8.34) & & $0(0)$ & $19(27.94)$ & & $2(2.94)$ & $17(25.00)$ & \\
\hline \multicolumn{13}{|l|}{ CAI9-9 (N=75) } \\
\hline$<180$ & $6(8.00)$ & $36(48.00)$ & 0.163 & $3(20.00)$ & $3(20.00)$ & 1.000 & $10(13.33)$ & $32(42.67)$ & 0.095 & $8(10.67)$ & $34(45.33)$ & 0.170 \\
\hline$\geq 180$ & $9(12.00)$ & $24(32.00)$ & & $5(33.33)$ & $4(26.67)$ & & $3(4.00)$ & $30(40.00)$ & & $2(2.67)$ & $3 I(4 I .33)$ & \\
\hline
\end{tabular}

Abbreviations: CA19-9, carbohydrate antigen 19-9; CEA, carcinoembryonic antigen; ECOG, Eastern Cooperative Oncology Group; GB, gallbladder; HBsAg, hepatitis B surface antigen; N, northern; N/A, no data; NE, north-eastern; C, central; S, southern; W, western.

Another study from China showed that $32.4 \%$ of patients with CCC had PIK3CA mutations. ${ }^{36}$ However, our study is the first to report the prevalence of $P I K 3 C A$ mutation in Thai patients with CCC. Interestingly, the $P I K 3 C A^{M u t+}$ group had significantly longer mPFS than did the PIK3CA $A^{M u t-}$ group. However, no previous study had analyzed patient survival in this group, although $\mathrm{Xu}$ et $\mathrm{al}^{36}$ found that $P I K 3 C A^{\text {Mut- }} \mathrm{CCC}$ was detected at a more advanced stage and in more aggressive forms.

We identified HER 2 expression in only 3 out of 74 samples (4\%), whereas Nakazawa et $\mathrm{al}^{26}$ identified HER2 overexpression in $15.7 \%$ of gallbladder carcinoma samples and $5.1 \%$ of extrahepatic bile duct carcinoma samples. We found strongly positive (3+) HER2 in 1 sample, from a patient who was diagnosed with early-stage disease and underwent curative surgery; 4 months later, he developed metastatic disease at lung, liver, adrenal gland, and lymph nodes. He received palliative chemotherapy, but unfortunately the disease was very aggressive, and his OS was 6 months after his diagnosis. This may imply that high HER 2 expression is associated with more aggressive tumors.

IHC for Ki-67 showed a median Ki-67 of $42.5 \%$. A previous study showed that high Ki-67 expression was correlated with advanced stage disease and could be used as a prognostic biomarker for CCC. ${ }^{48}$ We also found low median Ki-67 (22.5\%) in the $T 790 M$ mutation group, which correlated with longer survival.

We have validated our study's results by both Sanger direct sequencing technique and ddPCR technique; we found

Table 5 Median Ki-67 in each group of molecular analysis and tumor marker

\begin{tabular}{lll}
\hline Characteristics & Median Ki-67 & P-value \\
\hline EGFR mutation: negative vs positive & $40 \%$ vs $65 \%$ & 0.121 \\
EGFR mutation: non-T790M vs T790M & $80 \%$ vs $22.5 \%$ & 0.025 \\
KRAS mutation: negative vs positive & $45 \%$ vs $22.5 \%$ & 0.260 \\
PIK3CA mutation: negative vs positive & $47.5 \%$ vs 25\% & 0.273 \\
\hline
\end{tabular}

100\% concordance between ARMS-RT-PCR and ddPCR. This result was also similar to that of Zhang et $\mathrm{al}^{41}$ in a Chinese population. However, we found only 55.6\% concordance between Sanger direct sequencing technique and RT-PCR technique. Previous studies found that RT-PCR was significantly more sensitive in detecting mutation than Sanger DNA sequencing. Each technique has different limitations in detecting solid tumor mutations; for example, Sanger direct sequencing technique can detect 15\%-20\% mutant alleles, whereas ddPCR can detect low abundance mutations, present in only $0.02 \%$ of alleles. ${ }^{49,50}$ The ddPCR is a new technology to detect invasive genotyping of cfDNA in plasma, which can thus help detect acquired resistance in lung cancer. ${ }^{51-53}$

Our study had some limitations. First, because of the retrospective nature of the study, some data had been missing. Second, archival tissue specimens may suffer DNA damage, which can affect genomic alteration testing.

\section{Conclusion}

Cancer genetics may guide direct therapeutic decision in $\mathrm{CCC}$, including the use of targeted drugs. EGFR mutations and $P I K 3 C A$ mutations may imply and guide targeted therapy for CCC in the future, but due to the small sample size of this study, thus, we need to further explore in the larger population. Our study also suggested ARMS-RT-PCR or ddPCR for detecting low percentage of gene mutations.

\section{Acknowledgments}

The abstract of this paper (abstract no 2383) was presented at the European Cancer Congress 2015 as a poster presentation with interim findings. The poster's abstract was published in "Poster Abstracts" in the European Journal of Cancer: http:// www.ejcancer.com/article/S0959-8049(16)31299-0/abstract. This study was supported by grants from Ramathibodi Comprehensive Cancer Center, Faculty of Medicine Ramathibodi Hospital, Mahidol University, Thailand. This 
work is supported by The Thailand Research Fund and Medical Research Council-UK (Newton Fund). Project no DBG 598006.

\section{Disclosure}

The authors report no conflicts of interest in this work.

\section{References}

1. Tyson GL,El-Serag HB. Risk factors for cholangiocarcinoma. Hepatology. 2011;54(1):173-184.

2. Shaib YH, El-Serag HB, Davila JA, Morgan R, McGlynn KA. Risk factors of intrahepatic cholangiocarcinoma in the United States: a casecontrol study. Gastroenterology. 2005;128(3):620-626.

3. Oh JK, Weiderpass E. Infection and cancer: global distribution and burden of diseases. Ann Glob Health. 2014;80(5):384-392.

4. Jemal ABF, Bray F, Center MM, Ferlay J, Ward E, Forman D. Global cancer statistics. CA Cancer J Clin. 2011;61(2):69-90.

5. Petcharin S, Pattarawin A. Cancer incidence and leading sites. In Cancer In Thailand, Vol V; 2001-2003. Ministry of Public Health, Bangkok; 2010.

6. Shin HR, Oh JK, Masuyer E, et al. Epidemiology of cholangiocarcinoma: an update focusing on risk factors. Cancer Sci. 2010;101(3):579-585.

7. Sripa B, Kaewkes S, Sithithaworn P, et al. Liver fluke induces cholangiocarcinoma. PLoS Med. 2007;4(7):e201

8. Anderson CD, Pinson CW, Berlin J, Chari RS. Diagnosis and treatment of cholangiocarcinoma. Oncologist. 2004;9(1):43-57.

9. Butthongkomvong K, Sirachainan E, Jhankumpha S, Kumdang S, Sukhontharot OU. Treatment outcome of palliative chemotherapy in inoperable cholangiocarcinoma in Thailand. Asian Pac J Cancer Prev. 2013;14(6):3565-3568.

10. Raderer M, Hejna MH, Valencak JB, et al. Two consecutive phase II studies of 5-fluorouracil/leucovorin/mitomycin $\mathrm{C}$ and of gemcitabine in patients with advanced biliary cancer. Oncology. 1999;56(3): 177-180.

11. Penz M, Kornek GV, Raderer M, et al. Phase II trial of two-weekly gemcitabine in patients with advanced biliary tract cancer. Ann Oncol. 2001;12(2):183-186.

12. Glimelius B, Hoffman K, Sjödén PO, et al. Chemotherapy improves survival and quality of life in advanced pancreatic and biliary cancer. Ann Oncol. 1996;7(6):593-600.

13. Falkson G, MacIntyre JM, Moertel CG. Eastern cooperative oncology group experience with chemotherapy for inoperable gallbladder and bile duct cancer. Cancer. 1984;54(6):965-969.

14. Choi CW, Choi IK, Seo JH, et al. Effects of 5-fluorouracil and leucovorin in the treatment of pancreatic-biliary tract adenocarcinomas. Am J Clin Oncol. 2000;23(4):425-428.

15. Thongprasert $\mathrm{S}$. The role of chemotherapy in cholangiocarcinoma. Ann Oncol. 2005;16(suppl 2):ii93-ii96.

16. Ducreux M, Rougier P, Fandi A, et al. Effective treatment of advanced biliary tract carcinoma using 5 -fluorouracil continuous infusion with cisplatin. Ann Oncol. 1998;9(6):653-656.

17. Taïeb J, Mitry E, Boige V, et al. Optimization of 5-fluorouracil (5-FU)/ cisplatin combination chemotherapy with a new schedule of leucovorin, 5-FU and cisplatin (LV5FU2-P regimen) in patients with biliary tract carcinoma. Ann Oncol. 2002;13(8):1192-1196.

18. Valle J, Wasan H, Palmer DH, et al; ABC-02 Trial Investigators Cisplatin plus gemcitabine versus gemcitabine for biliary tract cancer. N Engl J Med. 2010;2010(362):1273-1281.

19. Valle JW. Advances in the treatment of metastatic or unresectable biliary tract cancer. Ann Oncol. 2010;21(supp1 7):vii345-vii348.

20. Terada T, Ashida K, Endo K, et al. c-erbB-2 protein is expressed in hepatolithiasis and cholangiocarcinoma. Histopathology. 1998;33(4): 325-331.
21. Tannapfel A, Benicke M, Kataline A. Frequency of p16INK4A alterations and k-ras mutations in intrahepatic cholangiocarcinoma of the liver. Gut. 2000;47(5):721-727.

22. Tannapfel A, Sommerer F, Benicke M, et al. Mutations of the BRAF gene in cholangiocarcinoma but not in hepatocellular carcinoma. Gut. 2003;52(5):706-712.

23. Aishima SI, Taguchi KI, Sugimachi K, Shimada M, Sugimachi K, Tsuneyoshi M. c-erbB-2 and c-Met expression relates to cholangiocarcinogenesis and progression of intrahepatic cholangiocarcinoma. Histopathology. 2002;40(3):269-278.

24. Endo K, Yoon BI, Pairojkul C, Demetris AJ, Sirica AE. ERBB-2 overexpression and cyclooxygenase-2 up-regulation in human cholangiocarcinoma and risk conditions. Hepatology. 2002;36(2):439-450.

25. Rashid A, Ueki T, Gao Y-T, et al. K-ras mutation, p53 overexpression, and microsatellite instability in biliary tract cancers: a population-based Study in China. Clin Cancer Res. 2002;8(10):3156-3163.

26. Nakazawa K, Dobashi Y, Suzuki S, Fujii H, Takeda Y, Ooi A. Amplification and overexpression of c-erbB-2, epidermal growth factor receptor, and c-met in biliary tract cancers. J Pathol. 2005;206(3): 356-365.

27. Ooi A, Suzuki S, Nakazawa K, et al. Gene amplification of Myc and its coamplification with ERBB2 and EGFR in gallbladder adenocarcinoma. Anticancer Res. 2009;29(1):19-26.

28. Kawamoto T, Krishnamurthy S, Tarco E, et al. HER receptor family: novel candidate for targeted therapy for gallbladder and extrahepatic bile duct cancer. Gastrointest Cancer Res. 2007;1(6):221-227.

29. Kim HJ, Yoo TW, Park DI, et al. Gene amplification and protein overexpression of HER-2/neu in human extrahepatic cholangiocarcinoma as detected by chromogenic in situ hybridization and immunohistochemistry: its prognostic implication in node-positive patients. Ann Oncol. 2007;18(5):892-897.

30. Yoshikawa D, Ojima H, Iwasaki M, et al. Clinicopathological and prognostic significance of EGFR, VEGF, and HER2 expression in cholangiocarcinoma. Br J Cancer. 2008;98(2):418-425.

31. Harder J, Waiz O, Otto F, et al. EGFR and HER2 expression in advanced biliary tract cancer. World J Gastroenterol. 2009;15(36):4511-4517.

32. Hezel AF, Deshpande V, Zhu AX. Genetics of biliary tract cancers and emerging targeted therapies. J Clin Oncol. 2010;28(21):3531-3540.

33. Pignochino Y, Sarotto I, Peraldo-Neia C, et al. Targeting EGFR/ HER2 pathways enhances the antiproliferative effect of gemcitabine in biliary tract and gallbladder carcinomas. BMC Cancer. 2010; 10:631.

34. Shafizadeh N, Grenert JP, Sahai V, Kakar S. Epidermal growth factor receptor and HER-2/neu status by immunohistochemistry and fluorescence in situ hybridization in adenocarcinomas of the biliary tree and gallbladder. Hum Pathol. 2010;41(4):485-492.

35. Gu TL, Deng X, Huang F, et al. Survey of tyrosine kinase signaling reveals ROS kinase fusions in human cholangiocarcinoma. PLoS One. 2011;6(1):e15640.

36. Xu RF, Sun JP, Zhang SR, et al. KRAS and PIK3CA but not BRAF genes are frequently mutated in Chinese cholangiocarcinoma patients. Biomed Pharmacother. 2011;65(1):22-26.

37. O'Dell MR, Huang JL, Whitney-Miller CL, et al. Kras(G12D) and p53 mutation cause primary intrahepatic cholangiocarcinoma. Cancer Res. 2012;72(6):1557-1567.

38. Dai R, Li J, Fu J, et al. The tyrosine kinase c-Met contributes to the pro-tumorigenic function of the $\mathrm{p} 38$ kinase in human bile duct cholangiocarcinoma cells. J Biol Chem. 2012;287(47):39812-39823.

39. Detarkom S. A Pilot Study of Molecular Alterations and the Clinical Prognostic Factors of Cholangiocarcinoma in Thai Population. Ramathibodi Hospital, Mahidol. Eur J Cancer. 2015;51(2):e9.

40. Wolff AC, Hammond ME, Hicks DG, et al; American Society of Clinical Oncology; College of American Pathologists. Recommendations for human epidermal growth factor receptor 2 testing in breast cancer: American Society of Clinical Oncology/College of American Pathologists clinical practice guideline update. J Clin Oncol. 2013; 31(31):3997-4013. 
41. Zhang B, Chun-Wei X, Yun S, et al. Comparison of droplet digital PCR and conventional quantitative PCR for measuring EGFR gene mutation. Exp Ther Med. 2015;9(4):1383-1388.

42. Leone F, Cavalloni G, Pignochino Y, et al. Somatic mutations of epidermal growth factor receptor in bile duct and gallbladder carcinoma. Clin Cancer Res. 2006;12(6):1680-1685.

43. Chang YT, Chang MC, Huang KW, Tung CC, Hsu C, Wong JM. Clinicopathological and prognostic significances of EGFR, KRAS and BRAF mutations in biliary tract carcinomas in Taiwan. J Gastroenterol Hepatol. 2014;29(5):1119-1125.

44. Gwak GY, Yoon JH, Shin CM, et al. Detection of response-predicting mutations in the kinase domain of the epidermal growth factor receptor gene in cholangiocarcinomas. J Cancer Res Clin Oncol. 2005;131(10): 649-652.

45. Wattanasirichaigoon S, Tasanakhajorn U, Jesadapatarakul S. The incidence of K-ras codon 12 mutations in cholangiocarcinoma detected by polymerase chain reaction technique. J Med Assoc Thai. 1998;81(5): 316-323.

46. Voss JS, Holtegaard LM, Kerr SE, et al. Molecular profiling of cholangiocarcinoma shows potential for targeted therapy treatment decisions. Hum Pathol. 2013;44(7):1216-1222.

47. Riener MO, Bawohl M, Clavien PA, Jochum W. Rare PIK3CA hotspot mutations in carcinomas of the biliary tract. Genes Chromosomes Cancer. 2008;47(5):363-367.
48. Zhao W, Zhang B, Guo X, et al. Expression of Ki-67, Bax and p73 in patients with hilar cholangiocarcinoma. Cancer Biomark. 2014;14(4): 197-202.

49. Zhang H, Zheng X, Ji T, et al. Comparative screening of K-ras mutations in colorectal cancer and lung cancer patients using a novel real-time PCR with ADx-K-ras kit and Sanger DNA sequencing. Cell Biochem Biophys. 2012;62(3):415-420.

50. Bárbara A, Esther C, Ana SG, et al. A comparison of EGFR mutation testing methods in lung carcinoma: direct sequencing, real-time PCR and immunohistochemistry. PLoS One. 2012;7(8):e43842.

51. Xu Q, Zhu Y, Bai Y, et al. Detection of epidermal growth factor receptor mutation in lung cancer by droplet digital polymerase chain reaction. Onco Targets Ther. 2015;8:1533-1541.

52. Oxnard GR, Paweletz CP, Kuang Y, et al. Noninvasive detection of response and resistance in EGFR-mutant lung cancer using quantitative next-generation genotyping of cell-free plasma DNA. Clin Cancer Res. 2014;20(6):1698-1705.

53. Hudecova I. Digital PCR analysis of circulating nucleic acids. Clin Biochem. 2015;48(15):948-956. 


\section{Supplementary materials}

Table SI List of mutation and cosmic ID identities of EGFR, PIK3CA, KRAS, and BRAF for ARMS-qPCR Amoy Kit

\begin{tabular}{|c|c|c|c|}
\hline Mutation & Exon & Base change & Cosmic ID \\
\hline G7I9A & 18 & $2156 \mathrm{G}>\mathrm{C}$ & 6239 \\
\hline G7I9S & 18 & $2155 G>A$ & 6252 \\
\hline G7I9C & 18 & $2155 G>T$ & 6253 \\
\hline E746_A750del (I) & 19 & 2235_2249dell5 & 6223 \\
\hline E746_A750del (2) & 19 & 2236_2249dell5 & 6225 \\
\hline L747_P753>S & 19 & 2240_2257dell8 & 12370 \\
\hline E746_T75I $>$ I & 19 & 2235_2252>AAT (complex) & $|355|$ \\
\hline E746_T75Idel & 19 & 2236_2253dell18 & 12728 \\
\hline E746_T75I $>A$ & 19 & 2237_225I dell5 & 12678 \\
\hline E746_S752>A & 19 & 2237_2254dell 8 & 12367 \\
\hline E746_S752>V & 19 & 2237_2255>T (complex) & 12384 \\
\hline E746_S752>D & 19 & 2238_2255dell8 & 6220 \\
\hline L747_A750>P & 19 & 2238_2248>GC (complex) & 12422 \\
\hline L747_T75I >Q & 19 & 2238_2252>GCA (complex) & 12419 \\
\hline L747_E749del & 19 & 2239_2247del9 & 6218 \\
\hline L747_T75Idel & 19 & 2239_2253dell5 & 6254 \\
\hline L747_S752del & 19 & 2239_2256dell 8 & 6255 \\
\hline L747_A750>P & 19 & 2239_2248TTAAGAGAAG $>C$ & 12382 \\
\hline L747_P753>Q & 19 & 2239_2258>CA (complex) & 12387 \\
\hline $747 \_T 751>S$ & 19 & $2240 \_225$ I dell 2 & 6210 \\
\hline L747_T75Idel & 19 & 2240_2254dell5 & 12369 \\
\hline L747_T75I >P & 19 & 2239_225I>C (complex) & 12383 \\
\hline T790M & 20 & $2369 \mathrm{C}>\mathrm{T}$ & 6240 \\
\hline S768I & 20 & $2303 \mathrm{G}>\mathrm{T}$ & 6241 \\
\hline H773_V774insH & 20 & 2319_2320insCAC & 12377 \\
\hline D770_N77IInsG & 20 & 2310_23IIinsGGT & 12378 \\
\hline V769_D770insASV & 20 & 2307_2308insGCCAGCGTG & 12376 \\
\hline L858R & 21 & $2573 T>G$ & 6224 \\
\hline L86IQ & 21 & $2582 \mathrm{~T}>\mathrm{A}$ & 6213 \\
\hline \multicolumn{4}{|l|}{ PIK3CA mutations } \\
\hline HI047R & 20 & CAT $>$ CGT & 775 \\
\hline HI047L & 20 & CAT $>$ CTT & 776 \\
\hline E542K & 9 & $\mathrm{GAA}>\mathrm{AAA}$ & 760 \\
\hline E545K & 9 & GAG $>A A G$ & 763 \\
\hline E542D & 9 & GAG $>$ GAT & 765 \\
\hline \multicolumn{4}{|l|}{ KRAS mutations } \\
\hline Gly 12Asp (GI2D) & 2 & GGT $>$ GAT & 521 \\
\hline Gly|2Ala (GI2A) & 2 & $\mathrm{GGT}>\mathrm{GCT}$ & 522 \\
\hline Gly 12 Val (GI2V) & 2 & GGT $>$ GTT & 520 \\
\hline Gly|2Ser (GI2R) & 2 & GGT >AGT & 517 \\
\hline Gly 12Arg (GI2R) & 2 & $\mathrm{GGT}>\mathrm{CGT}$ & 518 \\
\hline Gly 12Cys (GI2C) & 2 & GGT > TGT & 516 \\
\hline Gly|3Asp & 2 & GGC $>$ GAC & 532 \\
\hline \multicolumn{4}{|l|}{$B R A F$ mutations } \\
\hline V600EI & 15 & I799T $>A$ & 476 \\
\hline V600K & 15 & 1798_I799GT>AA (complex) & 473 \\
\hline V600E2 & 15 & 1799_I800TG >AA (complex) & 475 \\
\hline V600R & 15 & 1798_I799GT>AG (complex) & 474 \\
\hline V600DI & 15 & 1799_|800TG>AC (complex) & 478 \\
\hline V600D2 & 15 & 1799_I800TG >AT (complex) & 477 \\
\hline
\end{tabular}

Abbreviation: ARMS-qPCR, amplification-refractory mutation system-based quantitative polymerase chain reaction. 
Table S2 List of primers for direct sequencing EGFR (Ref seq: NG_007726.3)

\begin{tabular}{|c|c|c|c|c|c|c|}
\hline Target & Primer name & Primer sequence $\left(5^{\prime} \rightarrow 3^{\prime}\right)$ & $\begin{array}{l}\text { Length } \\
\text { (bp) }\end{array}$ & $\mathrm{Tm}$ & \%GC & $\begin{array}{l}\text { Product } \\
\text { Size (bp) }\end{array}$ \\
\hline \multirow[t]{2}{*}{ EGFR, exon 18} & EGFR-ExI8_7I9FP & TTGTGGAGCCTCTTACACCCAG & 22 & 72.6 & 54.5 & 185 \\
\hline & EGFR-Ex|8_7I9RP & GCTCCCCACCAGACCATGAGAG & 22 & 76.5 & 63.6 & \\
\hline \multirow[t]{2}{*}{ EGFR, exon 20} & EGFR-Ex20_768+790FP & ATTCATGCGTCTTCACCTGGAA & 22 & 72.9 & 45.5 & 252 \\
\hline & EGFR-Ex20_768+790RP & GAGCAGGTACTGGGAGCCAATA & 22 & 71.5 & 54.5 & \\
\hline \multirow[t]{2}{*}{ EGFR, exon 21} & EGFR-Ex2I_858+86IFP & TTTCAGGGCATGAACTACTTGG & 22 & 70.2 & 45.5 & 171 \\
\hline & EGFR-Ex21 $858+86 \mid R P$ & ССТССТTACTTTGССТССТTCTG & 23 & 71.5 & 52.2 & \\
\hline
\end{tabular}

Abbreviations: G, guanine; C, cytosine.

\section{Publish your work in this journal}

OncoTargets and Therapy is an international, peer-reviewed, open access journal focusing on the pathological basis of all cancers, potential targets for therapy and treatment protocols employed to improve the management of cancer patients. The journal also focuses on the impact of management programs and new therapeutic agents and protocols on patient perspectives such as quality of life, adherence and satisfaction. The manuscript management system is completely online and includes a very quick and fair peer-review system, which is all easy to use. Visit http://www.dovepress.com/testimonials.php to read real quotes from published authors. 